Sandrine Mathy, Patrick Criqui, Katharina Knoop, Manfred Fischedick, Sascha Samadi

\title{
Uncertainty Management and the Dynamic Adjustment of Deep Decarbonization Pathways
}

Originally published in:

Climate Policy, 16:sup1, 47-62

DOI: $10.1080 / 14693062.2016 .1179618$ 
Sandrine Mathy a*

Patrick Criqui a

Katharina Knoop $b$

Manfred Fischedick $b$

Sascha Samadi $b$

\section{Uncertainty Management and the Dynamic Adjustment of Deep Decarbonization Pathways}

a GAEL, CNRS, Grenoble INP, INRA, Université GrenobleAlpes, 38400 Saint Martin d'Hères, France

b Wuppertal Institute for Climate, Environment and Energy, Doeppersberg 19, 42103 Wuppertal, Germany

* Corresponding author:

Sandrine Mathy

GAEL, CNRS, Grenoble INP, INRA,

Université Grenoble-Alpes

38400 Saint Martin d'Hères

France

E-mail: sandrine.mathy@univ-grenoble-alpes.fr

This is the author's version of a work that was accepted for publication. Changes resulting from the publishing process, such as editing, corrections and structural formatting, may not be reflected in this document. Changes may have been made to this work since it was submitted for publication. A definitive version was subsequently published in the Journal cited above. 


\section{Uncertainty Management and the Dynamic Adjustment of Deep Decarbonization Pathways}

Sandrine Mathy ${ }^{1 *}$ (sandrine.mathy@univ-grenoble-alpes.fr), Patrick Criqui ${ }^{1}$ (patrick.criqui@univ-grenoble-alpes.fr), Katharina Knoop² (katharina.knoop@wupperinst.org), Manfred Fischedick ${ }^{2}$ (manfred.fischedick@wupperinst.org), Sascha Samadi² (sascha.samadi@wupperinst.org)

* Corresponding author

${ }^{1}$ GAEL, CNRS, Grenoble INP, INRA, Université Grenoble-Alpes, 38400 Saint Martin d'Hères, France

${ }^{2}$ Wuppertal Institute for Climate, Environment and Energy, Doeppersberg 19, 42103 Wuppertal, Germany

\section{Abstract}

Contrary to 'static' pathways that are defined once for all, this article deals with the need for policymakers to adopt a dynamic adaptive policy pathway for managing decarbonization over the period of implementation. When choosing a pathway as the most desirable option, it is important to keep in mind that each decarbonization option relies on the implementation of specific policies and instruments. Given structural, effectiveness and timing uncertainties specific to each policy option, they may fail in delivering the expected outcomes in time. The possibility of diverging from an initial decarbonization trajectory to another one without incurring excessive costs should therefore be a strategic element in the design of an appropriate decarbonization strategy. The article relies on initial experiences in France and Germany on decarbonization planning and implementation to define elements for managing dynamic adjustment issues. Such an adaptive pathway strategy should combine long-lived incentives to form consistent expectations, as well as adaptive policies to improve overall robustness and resilience. We sketch key elements of a monitoring process based on an ex ante definition of leading indicators that should be assessed regularly and combined with signposts and trigger values at the subsector level.

\section{Policy relevance}

These research questions are of special interest and urgency following the Paris Agreement in 2015, which calls on all countries to monitor the implementation of their national contributions and review their ambition regularly. The regular revision of decarbonization pathways constitute a great research opportunity to gather experiences on decarbonization pathway implementation and on dynamic management issues to progress toward an operational dynamic adaptive policy pathway mechanism.

\section{Keywords:}

mitigation scenario, France, Germany, dynamic adaptive pathways, decarbonization strategy 


\section{Introduction}

The energy system modelling community has extensively assessed the influence of technological and socio-economic uncertainties on low-carbon scenarios and associated costs (Markandya and Pemberton, 2010; Zeng et al., 2011; Kann and Weyant, 2000). Specific methods like sequential decision-making (Parson and Karwat, 2011) or robust decision-making (Lempert, 2000; Groves and Lempert, 2006) have been developed to choose optimal low carbon scenarios. This literature, however, has primarily approached scenarios in a way that can be described as "static", in that they are defined once for all and no explicit plan is defined for adjusting them in the face of changing circumstances.

However, most climate mitigation strategies rely on a number of innovative solutions (i.e. technologies, behavioral patterns, policy instruments, and institutional settings) for which implementation may face difficulties over time. There is therefore much uncertainty about the effectiveness of predefined pathways. In this paper we argue that decarbonization pathways spanning several decades cannot be defined once and for all in the first year, and that given the large uncertainties, the possibility of diverging from an initial decarbonization trajectory to another without incurring dramatically higher costs should be a strategic element in the design of decarbonization policy packages. They will likely need adjustments over time depending on the success of the chosen policies (and the induced technological change) and on changes in societal preferences that will appear along the way.

Planning paradigms have emerged to deal with such deep uncertainties. They consider policies as experiments that promote learning over time (Dewey, 1927) and policymaking as part of the storyline. The first step toward adaptive planning was the assumption based planning approach developed (Dewar, 1993) as a tool for improving the adaptability and robustness of existing plans, not as a tool for creating plans. It defines contingency plans and specified conditions, called signposts and triggers, under which the plan should be reconsidered and revised. Adaptive policymaking (Walker et al., 2001) provides mechanisms for hedging against negative outcomes and other uncertain events, for steering toward positive outcomes, and for adapting to changing situations. A key element of dynamic adaptive policymaking is a monitoring system with related contingency actions to keep the policy on track. The Dynamic Adaptive Policy Pathways approach (Haasnoot et al., 2011; Haasnoot et al., 2012) identifies promising pathways, defined as sequences of policy actions, in advance to avoid lock-ins. Such an approach is based on triggers called 'tipping points', which are conditions at which a policy begins to perform unacceptably and requires new actions to be implemented to achieve the objectives. It introduces flexibility into the strategy (rather than into the individual actions) by sequencing the implementation of actions over time in such a way that the system is adapted over time to changing social, economic conditions, etc. Such planning paradigms have received attention in various policy domains such as water management, climate adaptation, transport policies and other fields (Swanson and Bhadwal, 2009; Walker et al., 2010, or Haasnoot et al., 2013), but not yet in the field of decarbonization pathways.

The contribution of this article is to analyze the adaptive adjustment dimension of designing decarbonization pathways. We will try to reveal these adjustment capabilities while comparing energy transition scenarios in Germany and France, two countries similar in terms of geography, development and culture, but characterized by marked differences in their energy systems. 
A key conclusion of the paper is that a decarbonization strategy should include the possibility of diverging from an originally pursued pathway to another one without incurring excessive costs. Such an adaptive pathway strategy should combine long-lived incentives to form consistent expectations, as well as adaptive policies to improve overall robustness and resilience. A monitoring process based on different sets of indicators would help monitor progress and indicate in time when course adjustments may be needed.

In Section 2, we highlight dynamic management issues specific to each decarbonization option and corresponding policies and instruments. Section 3 describes adaptive pathways issues associated with decarbonization pathways chosen in France and Germany. Section 4 proposes a framework for addressing dynamic management issues related to decarbonization pathways in order to limit the need for adjustment over time and its cost.

\section{Structural uncertainties in transitions: policies and instruments}

In this section, we identify the structural uncertainties associated with the three main decarbonization pillars identified in deep decarbonization pathways for France and Germany (Mathy et al., 2015; Hillebrandt et al., 2015): energy efficiency, energy supply decarbonization and switching energy end-uses to lower-carbon energy carriers. We discuss the capacity of different policies and economic instruments to achieve predefined quantified targets. In doing so we aim to demonstrate and highlight that uncertainties inherent to the effectiveness and efficiency of the policies and instruments addressing each decarbonization pillar lead to specific dynamic management issues.

\subsection{Massive final energy demand reduction: the easiest way or a slow lane?}

Final energy demand reduction involves both energy efficiency improvements and changes in consumer behavior. The "energy-efficiency" gap problem is well-known: even if energy efficiency improvements are justified from a standard cost-benefit analysis, such operations are difficult to trigger in real life, due to short horizons of decision-makers, substantial transaction costs and funding difficulties (Schleich and Gruber 2008; Chai and Yeo, 2012; Jaffe and Stavins, 1994). In much of Europe, the deep thermal retrofit of buildings is often identified as the main challenge to be won in the energy transition. However, the actual triggering of large scale residential retrofitting programs has never occurred in the past. Transaction costs are substantial, funding is difficult to secure, and building owners demand a short return on investment (DeCanio, 1998) that automatically translates into a high implicit discount rate. The "Landlord-Tenant dilemma" is also a major issue: the landlord is supposed to commission the operation, but as he does not pay for energy consumption, he usually has little incentive to invest in the energy efficiency of the dwelling.

Various policies can narrow the gap between collective and individual rationales, through subsidies or environmental taxes, but special attention must be paid in order to avoid adverse effects on public or households' budgets. Success will depend, to a large extent, on the government's ability to frame policies (i.e. articulating energy prices, suitable funding, lower transaction costs), professional training and adequate business structures to stimulate building retrofitting at a very large scale (Bullier and Milin, 2013). 


\subsection{Deep decarbonization of energy supply: no silver bullet!}

There are several options for decarbonizing the energy supply: renewable energy sources, nuclear or fossil fuels with carbon capture and storage (CCS) for electricity, biofuels, hydrogen, and synthetic gases and liquids. But every option faces challenges and technology specific uncertainties. In the following section we will make this point by focusing on the decarbonization of electricity generation.

The first challenge for the massive deployment of low-carbon technologies for electricity generation corresponds to the fact that for the most part they still depend on significant subsidies. However, many electricity generation technologies using renewable energy sources have become much more cost-competitive in recent years, partly due to economies of scale driven by these selfsame subsidies. Environmental and climate policies have accelerated the pace of innovation in low carbon technologies (Dechezleprêtre et al., 2011). It has been found that different types of policy instruments are effective for different renewable energy sources. Broad-based policies, such as tradable energy certificates, are more likely to induce innovation in technologies that are close to competitive with fossil fuels. More targeted subsidies, such as feed-in tariffs, are needed to induce innovation in more costly energy technologies, such as solar PV in the past (Johnstone et al., 2010). But maintaining a high level of incentives for a rapid development of renewables can quickly become unsustainable (Marcantoni and Ellerman, 2015) unless cost-competitiveness is reached fairly rapidly.

The second limit refers to the integration of high shares of variable renewable electricity (VRE) in the grid (Hirth et al., 2015). Several deep decarbonization scenarios granting priority to renewables project $50 \%$ or more VRE in the electricity mix (DDPP, 2015). Even at relatively low VRE market shares - less than $30 \%$ - the network incurs various system costs: transmission costs for connecting more widely dispersed generating plants, the buildup of reserve capacities, market restructuring, and reoptimization of the power plant fleet to minimize ramping costs.

Increasing the share of VRE in the power generation mix poses the problem of a structural mismatch, at certain periods of the year, between the grid demands and the power supplied. At times, VRE produces a massive surplus. Research carried out in Germany and France suggests that, with current demand profiles, when VRE accounts for more than $40 \%$ of output, significant surplus production starts occurring (Wagner, 2014; Grand et al., 2014). Unless storage or increased transmission to other jurisdictions with unmet demand are implemented, large unused production would reduce the cost-effectiveness of VRE, but both options have costs.

Focusing on nuclear energy would also require removing significant barriers. The increasing size and complexity of third-generation nuclear plants lead to significant delays in the building of the first third-generation projects in Finland and France, delays already manifesting in the secondgeneration's steadily rising costs (Grübler, 2010; Lévêque, 2014). Expected costs for future thirdgeneration projects are rising. Costs for the first prototype in France were revised upwards to $€ 6,300 / \mathrm{MWe}$ (Bezat, 2015), five times the cost of the last nuclear reactor built in France (Escobar Rangel and Lévêque, 2015). Using multiple expert elicitations, Anadon et al. (2013) show that a doubling of public nuclear RD\&D is expected to result in cost reductions of only about $8 \%$ in 2030 . The predicted cost for future nuclear power in France (Boccard et al., 2014) compares unfavorably against alternative power generation options. Beyond the first pilot plants, these difficulties will have to be overcome while keeping the desired level of safety, notwithstanding the commonly raised 
issues of waste management, potential occurrence of large-scale accidents or terrorist attacks, and social acceptability.

The development of CCS is also subject to major uncertainties. The R\&D for this immature technology would be only justified if investors were certain enough about a deep decarbonization policy process with a $\mathrm{CO}_{2}$ price sufficient to compensate for the significant additional costs of integrating CCS into power plants. Currently, the low carbon prices all around the world are not sufficient to support CCS. The number of large scale integrated CCS projects is smaller than expected a few years ago and decreasing (Kern et al., 2016), and many of them face delays. Some projects have even been cancelled because of difficulties in assembling viable business solutions (Global CCS Institute, 2013). The risk that this technology will not be ready on time or will prove incapable of ramping up to industrial deployment capability needs to be considered.

\subsection{Switching energy end-uses to low carbon energy carriers}

The third pillar is focused on the electrification of end-uses, and particularly the diffusion of electric and hybrid vehicles. However, at 2015 oil prices, the economic fundamentals of electric vehicles are frail: with an initial extra investment cost of $€ 8,000-10,000$ over a conventional car and annual energy savings of about $€ 1,000$, the payback period is at best 8 years. This is probably insufficient considering observed consumer behavior and the corresponding implicit discount rates as seen in the energy-efficiency gap. France's introduction of a $€ 6,000$ incentive for electric vehicle may help to stimulate sales, but it may endanger public finances in case of rapid take-off of electrical vehicles. A substantial and lasting reduction in the payback period would thus require both technical advances and/or a steep rise in gasoline prices, perhaps through the introduction of a carbon tax.

\subsection{Specific dynamic adjustment issues of decarbonization options}

As seen above, most options for decarbonization and their respective policies are characterized by uncertainties about their capacity to reach an adequate deployment level: for example, R\&D may fail to deliver next generation nuclear reactors or CCS technologies at competitive costs or on time. For other options, including renewable development, electrification of end-uses or final energy demand reduction, the main technologies are already available and supply-side uncertainty is therefore much smaller, but there is uncertainty in regard to how quickly these technologies, given consumers and firms behavioral responses. There is, however, a diversified portfolio of options here (including e.g. solar energy, wind energy, biomass, building retrofit, industrial efficiency, lifestyle changes) to achieve overall targets even when a single element may fail to deliver to the expected extent. Relying on a large number of different strategies and technologies helps to preserve future options. The performance of policies may also be limited by the economic burden that subsidies and incentives may represent if costs do not decrease fast enough, or by a lack of accompanying policies addressing non-economic barriers. The specifics of each decarbonization option and their combinations need to be considered when integrating dynamic management issues within a decarbonization strategy.

\section{Adaptive dynamic pathways issues in France and Germany}

In this section we describe the debates and processes in France and Germany that lead to the main pillars of the countries' national decarbonization strategies. They implicitly delineate a narrowed 
range for preferred decarbonization pathways. The two countries have now reached the stage of implementation for their respective decarbonization pathways and face dynamic adjustment issues. These case studies help to identify elements that are able to address such adjustment issues.

\subsection{France: "la transition énergétique"}

In 2013, the National Debate on Energy Transition defined two main pillars for energy transition. The Factor Four target for emissions in 2050 (a GHG emission reduction to $25 \%$ of the level of 1990) was officially introduced in 2005 . The second pillar is the reduction to $50 \%$ by 2025 of nuclear power's share in the electricity mix. This dates from the 2012 presidential election campaign, when the idea was introduced to diversify the electricity mix.

The council of the National Debate on Energy Transition launched an inventory of existing long-term low carbon energy scenarios for France. Sixteen scenarios coming from non-profits, NGOs, research centers or other stakeholder in the energy economy were selected. Preliminary analysis revealed huge differences, with electricity consumption varying for example between 280 and $840 \mathrm{TWh}$ in 2050, compared with 450 TWh today (Arditi, 2012).

Ultimately a typology of four "trajectories" appeared compliant with the dual pillars referred to above (with one exception discussed below), but very different in their structure and socio-economic implications. Two essential characteristics distinguish these pathways (Table 1): the demand level, as measured by the reduction of total final energy demand by 2050; and the supply mix, measured by the relative weight of nuclear and renewable energy in electricity generation.

Table 1 : Four pathways for a low carbon transition in France

\begin{tabular}{|c|c|c|c|}
\hline & & \multicolumn{2}{|l|}{ Supply-side mix } \\
\hline & & Diversification & Priority to one source \\
\hline \multirow{2}{*}{$\begin{array}{l}\text { Final energy } \\
\text { demand } \\
\text { reduction in } \\
2050 \text {, } \\
\text { compared to } \\
2010\end{array}$} & $-20 \%$ & $\begin{array}{l}\text { Diversity } \\
\text { - } \quad \text { Strong reduction in consumption } \\
\text { comes at a cost } \\
\text { - } \quad \text { Electricity mix: } \\
\text { - Share of nuclear power } \\
\quad \text { stabilized at } 50 \% \text { after } 2025 \\
\text { - } 40 \% \text { share of renewables by } \\
2050\end{array}$ & $\begin{array}{l}\text { Decarbonization } \\
\text { - Strong reduction in consumption comes } \\
\text { at a cost } \\
\text { - Electricity mix: } \\
\text { - Nuclear power retains its } 75 \% \\
\text { - } \quad \text { Rhare } \\
\text { Renewables limited at } 20 \%\end{array}$ \\
\hline & $-50 \%$ & $\begin{array}{l}\text { Efficiency } \\
\text { - Cut in consumption through use of } \\
\text { best available technologies } \\
\text { - Electricity mix: } \\
\text { - Share of nuclear decreases } \\
\text { after 2025, down to } 25 \% \text { in } \\
2025 \\
\text { - } 70 \% \text { share of renewables by } \\
2050\end{array}$ & $\begin{array}{l}\text { Sobriety } \\
\text { - Major changes in consumer behavior } \\
\text { - } \quad \text { Electricity mix: } \\
\text { - } \quad \text { Complete phase-out of nuclear } \\
\text { - } \quad 90 \% \text { sher by } 2050 \\
2050\end{array}$ \\
\hline
\end{tabular}

Source: Arditi et al., 2012. 
Setting aside the hypothesis of a major game-changing, technological advance, it is hard to imagine a low carbon future completely at odds with the range described by these four pathways. They thus provide a plausible range of energy futures for France. At one extreme Sobriety is inspired by the scenario developed by the negaWatt French NGO and is characterized by the combination of ambitious energy conservation, energy efficiency and renewable development that makes possible a nuclear phase-out. At the other extreme Decarbonization is inspired by the scenario developed by Negatep, an NGO composed mostly of retired people from the French Atomic Energy Commission (CEA) in which nuclear power generation increases strongly under the combined effect of a major electrification process and a $75 \%$ share for nuclear power. Between the two, Efficiency is very close to the scenario elaborated by France's Environment and Energy Management Agency (ADEME), and Diversity draws on one scenario produced by the National Alliance for the Coordination of Energy Research, which adopts a balanced position between the various forms of leverage and sources of low carbon energy.

The resulting law on Energy Transition for Green Growth does not explicitly refer to these pathways. It is nevertheless fairly easy to characterize the scenario which will result from the enforcement of its provisions as the law sets clear quantitative targets (see Supplementary material).

The law appears clearly consistent with the Efficiency pathway. Nevertheless, reaching a $50 \%$ reduction in final energy is a real challenge, particularly because of the required retrofitting of the existing building stock. If this objective cannot be effectively implemented, more decarbonized energy will be needed. This is why in France dynamic adaptive pathway management mainly refers to a tradeoff between Efficiency and Diversity, the latter of which imposes the need for more nuclear. Sobriety could also be considered as an alternative to Efficiency in the case of the decision to phaseout nuclear, but this is not currently being considered for France. By contrast, in Decarbonization, nuclear power retains its $75 \%$ share until 2050 , which contradicts the official objective of reducing the nuclear share in the electricity mix to $50 \%$ in 2025 . Moreover, Decarbonization is the opposite of Efficiency according to the two dimensions of the typology (Table 1) and represents a contrasted vision of the evolution toward a decarbonized energy system compared to Efficiency.

The settings for the energy transition in France clearly call a watchful dynamic management over time. Indeed, the law includes two complementary items that may allow an adaptive capability while integrating long-lived incentives. First, the future value of the carbon component of energy taxes is registered in the law: it will increase from $22 € / \mathrm{tCO}_{2}$ in 2016 to respectively 56 and $100 € / \mathrm{tCO}_{2}$ in 2020 and 2030 - these values are consistent with experts recommendations (Quinet, 2009); second, the expert committee of the National Low Carbon Strategy is currently working for the implementation of a five-year rolling process for the monitoring and adjustment of the sectoral targets.

\subsection{Germany: "die Energiewende"}

In 2010, the German government adopted its Energy Concept for an Environmentally Sound, Reliable and Affordable Energy Supply. Besides the key target of reducing GHG emissions by $40 \%$ by 2020 and by $80-95 \%$ by 2050 , a variety of sub-targets were set (see Supplementary material).

As part of the Energy Concept, the government also announced that the country's existing nuclear power plants would be allowed to run longer than previously planned, until at least the mid-2030s. This controversial decision was revoked a year later following the Fukushima accident when the German government announced a nuclear phase-out by 2022, largely reverting back to the original 
schedule devised in the early 2000s. The climate and energy targets of the Energy Concept remained for the most part unchanged, however.

Rejecting nuclear power and CCS due to a lack of public and political acceptance obviously limits the options available for decarbonizing the energy supply. Furthermore, the reliance solely on renewable energy sources on the supply side makes strong final energy demand reductions more important.

In German decarbonization scenarios, renewable energy sources make up more than $30 \%$ of total primary energy supply in 2030 and more than 50\% in 2050, growing from 11\% in 2014. Scenarios expect final energy demand to be reduced by $40 \%$ to $47 \%$ by 2050 compared to 2010 . This would require much faster efficiency increases than in the past: between 2008 and 2014 final energy productivity in Germany grew by $1.6 \% / \mathrm{yr}$, while in the mitigation scenarios it has to increase to 2.3\%/yr between now and 2050. Reductions in final energy demand are expected to be achieved mainly by energy efficiency improvements and - to a lesser extent - reductions in energy service demand compared to a reference case.

As more than five years have passed since the adoption of the Energy Concept, some uncertainties and challenges to the German efficiency-renewables pathway have already been experienced. In general, there is no lack of technologies but a lack of a concept to bring them into the market (i.e. an answer to the question of how to shape the right institutional, cultural and social environment for a successful deployment path). This is underlined by the fact that Germany is at risk of falling short on several national climate and energy objectives for 2020, mainly due to the below-target energy intensity improvements in recent years.

Several concrete challenges have been identified (Löschel et al. 2012, 2014a, 2014b, 2015; Hillebrandt et al., 2015; Fischedick, 2014). Given the current share of electricity from renewable energy sources (33\% in 2015), further flexibility options are required quickly to keep the electricity grid stable. In order to guarantee sufficient investment in those flexibility options, a new electricity market design has to be introduced which provides reliable and stable investment conditions. Concerning final energy demand reduction, $2 \%$ of the building stock needs to be retrofitted each year, but from 2005 to 2008, this rate amounted to $1 \% / y r$ only. This rate should be raised in the short-term and the depth of retrofits should be increased to avoid a lock-in resulting from the fact that buildings refurbished superficially are not expected to be renovated again before 2050. More generally, another issue for a successful "Energiewende", is the need to develop initiatives helping to ensure public acceptance for required infrastructure projects.

Since 2012, the German government has regularly published a monitoring report describing the status of implementation of "Energiewende" measures and the degree of target achievement (BMWi/BMU, 2012; BMWi, 2014a, 2014b, 2015). A number of energy system indicators describing the progress of the "Energiewende" are presented, updated and discussed. Furthermore, every three years a "progress report" is to be submitted by the government which analyses the status quo of the "Energiewende" process in the overall context and suggests - if necessary - additional policies and measures. At the end of 2014 the first progress report was released (BMWi, 2014b). It concluded that the "Energiewende" process was well on track in some regards, such as in the increase of electricity generation from renewable sources, while additional efforts and policies were needed (and planned) in other regards, such as in the pace of energy efficiency improvements and GHG emission reductions. 
Scientific support for the monitoring process is provided by an independent commission which consists of four prominent energy system researchers from different scientific institutions in Germany. They analyze each monitoring report and provide feedback from a scientific perspective. The expert commission's analyses (Löschel et al., 2012, 2014a, 2014b, 2015) of the government's first four monitoring reports suggested several improvements regarding "Energiewende" measures in the areas of energy efficiency, renewables and their economic effects, but also several procedural improvements for the German government's monitoring process.

One of the procedural improvements suggested by the commission was the prioritization of "Energiewende" targets. This suggestion has meanwhile been adopted by the German government. The target structure now shows that there are overriding targets (especially GHG emission reductions and the nuclear phase out by 2022) that have highest priority, while additional targets are defined that intent to support these overriding targets. The additional targets can be subject to changes in the future if the strategies pursued need to be adjusted in order to achieve the overriding targets.

Other suggestions by the expert commission have not (yet) been adopted by the government. These include:

- advancing the set of indicators used in the monitoring reports to ensure that progress in realizing the "Energiewende" targets can be assessed more thoroughly (see suggested lead indicators in Table 2);

- focusing on a detailed analysis and assessment of developments instead of merely describing changes in indicators over time and distinguishing clearly between the role of endogenous factors (specific policies) and exogenous factors (price developments on international markets) in explaining past changes in indicators.

Table 2: Lead indicators suggested by the expert commission

\begin{tabular}{|l|l|}
\hline \multirow{2}{*}{$\begin{array}{l}\text { Superordinate } \\
\text { targets }\end{array}$} & Greenhouse gas emissions \\
\cline { 2 - 2 } & Phase-out of nuclear power \\
\hline Energy supply & Share of renewables in gross final energy consumption \\
\cline { 2 - 2 } & Final energy consumption \\
\hline Security supply & Average outage duration for electricity \\
\cline { 2 - 2 } & Power balance \\
\hline Economic \\
viability & Innovation \\
\cline { 2 - 2 } & National energy accounts \\
\hline Society & Social impacts (high cost/ low income) \\
\cline { 2 - 2 } & Acceptance \\
\hline
\end{tabular}

Source: Löschel et al., 2014b 


\subsection{The need for and potential of dynamic adjustments in France and Germany}

In both countries, the national debate on energy has settled on implicit adoption of a desirable future combining high levels of renewable diffusion and an ambitious reduction in final energy demand (of about $40 \%$ to $50 \%$ by 2050 compared to today). Reaching such ambitious targets is a real challenge. The pathways laid out in both countries cannot be considered as static. Potential adjustments from the central decarbonization pathways need to be anticipated and planned for.

In France, the main uncertainty of the central decarbonization pathway is the ability to halve final energy demand and particularly to retrofit almost all the existing building stock in 35 years. The room for maneuver would be an increased use of nuclear energy. As it is not possible to be sure that the construction time of new nuclear plants could be less than 10 years, alternatives to central decarbonization pathway options should be considered in due time in a monitoring process.

In Germany the nuclear energy phase-out decision limits the range of alternatives and all available decarbonization pathways point to an intensive development of renewable energy sources and strong energy demand reductions, although behavioral changes concerning energy demand are usually considered and analyzed only to a very limited extent.

Each case study provides instructive elements to design of a comprehensive mechanism able to manage the dynamic adjustment issues related to decarbonization pathways. The German monitoring process continuously examines a set of key indicators which can help to identify in due time whether adjustments from the originally devised pathway are needed. This is a central element for managing uncertainties over time without incurring excessive costs. However, a key challenge to the dynamic management of decarbonization is that if economic actors are initially aware that the management will be "dynamic", this will modify their expectations and may lead to required investments being delayed due to a "wait-and-see", option value maximization approach by investors. In France, the adoption of an increasing carbon price trajectory between 2015 and 2030 consistent with medium and long term mitigation according to economic experts is a central piece to assure investors that their low-carbon investments will pay off irrespective of future changes to certain elements of the original decarbonization vision.

\section{The need for combining long lived incentives and adaptive policies, through a continuous monitoring process}

In this section, we describe a framework for addressing dynamic management issues related to decarbonization pathways in order to limit the need for adjustment and associated costs over time. This proposal is based on the academic literature on adaptive policies and pathways, on the specific uncertainties associated with policies and instruments needed to reach decarbonization objectives, and on the French and German experiences with deep decarbonization strategies.

\subsection{The need for combining long lived incentives and adaptive policies}

An adaptive pathway strategy designed to achieve a full deep decarbonization energy transition in only three or four decades should combine long lived incentives and adaptive policies. If only adaptive policies were chosen, actors could modify their expectations in negative ways associated 
with a "wait and see" attitude. Blyth et al. (2007) emphasize the role of long-term regulatory certainty to minimize investment risks in low carbon technologies. The implementation of a preestablished increasing carbon tax as a central price signal allows consumers and investors to form stable expectations, facilitating long-term decisions in innovation, the deployment of new infrastructure, and investment in long lived assets. Other sectoral instruments and policies will be needed to address capital costs, insurance premiums, certification of alternative technologies, structure of tax systems, land pricing, road pricing and other transport regulations. Such policies will be deployed under national constraints imposed by numerous non-energy related objectives, such as reducing government debt levels, enhancing economic activity, and investment in the context of a currently depressed economic climate, high unemployment and stagnating or declining households' purchasing power.

\subsection{Robust strategies, resilient systems}

In order to limit the effect of uncertainties on the implementation of the decarbonization pathway, the policies deployed must be designed to give priority to components which will make them more robust and resilient. Robustness means that preference should be given to policies suited to very different environments, at the domestic and international level (Lempert, 2000). Resilience requires energy systems which continue to run, or at least quickly recover, in the event of crises, accidents or acute instability. Finding robust solutions hinges on the adaptation strategies, whereas solutions which enhance resilience have more to do with the nature of the technological systems deployed.

Uncertainty can be managed in such a way as to encourage robust strategies and resilient systems by distinguishing three categories of actions: policies that are common to many pathways, at least during the initial launching phase; policies that are constrained by severe inertia and delays in response or deployment, for which allowance must be made in the timing of decisions; and lastly, policies which preserve future freedom of choice, yielding high option-value.

Subject to these guidelines, all the scenarios involve rolling out policies to enhance energy efficiency and decarbonize final energy. Leading up to 2030, such policies must be deployed with approximately the same intensity in most scenarios: they are thus probably robust options to be prioritized.

For the energy efficiency and renewable energy solutions, the roll-out time is only one or two years, starting from the decision to invest. Then, the main difficulty relates to ramp-up, which must be achieved with sufficient speed and volume. As a consequence, it is necessary to trigger a large number of investment decisions by a very large number of decision-makers. The supply-side options for large generating facilities and the development of networks and storage infrastructures pose a problem of a very different nature. Such investments are often very large and indivisible, with long lead and payback times. Lastly, they are in many respects irreversible. The real-option approach can be a good methodology for exploring these issues (Kumbaroğlu et al., 2008; Yang et al., 2008; Ritzenhofen et al., 2015). Real-options theory is an approach for economic valuation of projects under uncertainty. It focuses on the managerial flexibility (the "option") value to optimally respond to a changing scenario characterized by uncertainty. Investment decisions should consequently take into account the capacity of actions to generate option-value to acquire more information and broaden the scope of possible future outcomes. 


\subsection{Framework for a monitoring process}

We propose some elements for designing a monitoring process for an adaptive policy-making process. The framework follows recommendations made by Walker et al. (2001) and includes:

1. Stage setting:

a. The definition of a "first best" pathway characterized by explicit:

- high level targets (such as nuclear phase-out in Germany);

- structural ( $X \%$ renewables and $Y \%$ of final energy reduction in 2050 for example) and sectoral objectives;

- translation of sectoral targets in a timetable of sub-sectoral targets (e.g. number of sales of electric vehicles, of additional GW in PV each year) and their induced GHG emission reductions.

b. The definition of a set of structural non-climate priorities (energy security, energy poverty, industrial competitiveness, energy prices for consumers...) and specific assessment indicators.

c. The definition of a set of policies to be implemented to reach sub-sectoral targets.

2. The definition of robust and resilient policies consistent with sub-sectoral objectives and non-climate priorities.

3. The assessment of the consistency of policies with the subsector objective. For each subsector objective, the monitoring grid should define essential elements that will need to be periodically checked:

- The list of policy options that address the subsector objective;

- Effective contribution to the sub-sectoral objective;

- Signpost and trigger values that would help tracking if a policy reassessment is needed. Beyond mitigation efficiency, such signposts would address non-climate priorities that have been defined, including:

0 the effective cost to public or consumer finances (e.g. for FITs) of the policy and potential adverse consequences;

- signpost and trigger values defined according to a timescale specific to each policy, taking into account the time needed for deployment.

- If triggered values are reached additional actions are needed. These can be either corrective actions if an adjustment of the policy is considered as being enough, or a deeper reassessment if it is judged the policy needs to be redesigned.

- If a reassessment of the policy is needed, will this require redefinition of sub-sectoral targets?

The continuous monitoring of policy implementation will lead to the revision of energy transition policies when trigger values are reached for specific sub-sectoral targets. The definition of trigger values and policy changes needed when trigger values are reached should be done upstream of policy implementation to ensure consistency with high level strategy. The implementation of such a framework can be facilitated by the development of dynamic adaptive policy pathways such as proposed by Kwakkel et al. (2015) or by Haasnoot et al. (2013). 


\section{Conclusion}

The academic literature has extensively explored issues related to optimal choice of low-carbon scenarios given technological and socio-economic uncertainties. Such approaches, however, consider scenarios as 'static' pathways that are defined once for all and that would not need to be adjusted over time. On contrary, this article deals with the need for policymakers to adopt a dynamic adaptive policy pathway for managing decarbonization over the period of implementation. When choosing a pathway as a more desirable option, it is important to have in mind that each decarbonization option relies on the implementation of specific policies and instruments. But given structural, effectiveness and timing uncertainties specific to each policy option they may fail in delivering the expected outcomes in time. The possibility of diverging from an initial decarbonization trajectory to another one without incurring excessive costs should therefore be a strategic element in the design of an appropriate decarbonization strategy.

Experiences in France and Germany confirm the need for managing dynamic adjustment issues related to decarbonization pathways. Main pieces of the predefined decarbonisation strategy, such as the energy efficiency improvement or the level of renewable development, have been slower than expected. Nevertheless, both countries' low carbon strategies already contain instructive elements for managing dynamic adjustment issues. On the one hand, the German monitoring process contains interesting elements to identify necessary adjustments in time, and on the other hand, the determination of an increasing carbon value in France is a central strategy to ensure a stable environment for low carbon investments and thus to limit the need for adjustment over time.

On a more general level, the article proposes a framework for addressing dynamic management issues related to decarbonization pathways in order to limit the need for adjustment over time and its cost. Such an adaptive pathway strategy should combine long-lived incentives to form consistent expectations, as well as adaptive policies to improve overall robustness and resilience. We describe the beginning elements of a monitoring process based on an ex ante definition of leading indicators that should be assessed regularly and combined with signposts and trigger values at the subsector level. Conscious watchfulness for unanticipated adverse effects and potential failures of policies could limit irreversibility effects and the need for costly readjustments of the deep decarbonization policy package.

The framework for addressing such dynamic management issues in long-term decarbonization pathways needs further operational research. The definition of lead indicators, specific signposts and trigger values should be quantified for real decarbonization pathways and experimented on in real life. The assessment that the window of opportunity for a decarbonization option has closed must be foreseen early enough in order that other decarbonization options can be deployed. These research questions are of special interest and urgency following the Paris Agreement, which calls on all countries to monitor the implementation of their national contributions and review their ambition regularly. 


\section{Acknowledgements}

The authors gratefully acknowledge the helpful comments of four anonymous reviewers and the generous assistance of Chris Bataille from IDDRI.

\section{References}

Anadon, L. D., Nemet, G., \& Verdolini, E. (2013). The future costs of nuclear power using multiple expert elicitations: effects of RD\&D and elicitation design. Environmental Research Letters, 8(3), 034020 .

Arditi, M., et al., 2012. Quelle trajectoire pour atteindre le mix énergétique en 2025? Quels types de scénarios possibles à horizons 2030 et 2050, dans le respect des engagements climatiques de la France? Rapport du groupe de travail $n^{\circ} 2$ du conseil national sur la transition énergétique. $72 p$.

Bezat, J.-M. Nucléaire: la facture de l'EPR s'alourdit encore. Le nouveau réacteur de Flamanville devrait être mis en service fin 2018, Le Monde, 4 septembre 2015.

Blyth, W., Bradley, R., Bunn, D., Clarke, C., Wilson, T., \& Yang, M. (2007). Investment risks under uncertain climate change policy. Energy policy, 35(11), 5766-5773.

BMWi, Federal Ministry for Economic Affairs and Energy (2014a). Zweiter Monitoring-Bericht, „Energie der Zukunft“. Berlin.

http://www.bmwi.de/BMWi/Redaktion/PDF/Publikationen/zweiter-monitoring-bericht-energie-derzukunft, property=pdf, bereich=bmwi2012, sprache=de, $r w b=$ true. $p d f$

BMWi, Federal Ministry for Economic Affairs and Energy (2014b). Die Energie der Zukunft. Erster Fortschrittsbericht zur Energiewende. Berlin.

http://www.bmwi.de/BMWi/Redaktion/PDF/Publikationen/fortschrittsbericht,property=pdf, bereich $=$ bmwi2012,sprache=de, rwb=true.pdf

BMWi, Federal Ministry for Economic Affairs and Energy (2015). A good piece of work, The Energy of the Future, Fourth "Energy Transition" Monitoring Report - Summary. Berlin.

http://www.bmwi.de/English/Redaktion/Pdf/vierter-monitoring-bericht-energie-der-zukunftkurzfassung, property=pdf, bereich=bmwi2012, sprache=en, rwb=true.pdf

BMWi, Federal Ministry of Economics and Technology, BMU, Federal Ministry for the Environment, Nature Conservation and Nuclear Safety (2012). Erster Monitoring-Bericht „Energie der Zukunft“. Berlin.

http://www.bmwi.de/BMWi/Redaktion/PDF/Publikationen/erster-monitoring-bericht-energie-derzukunft, property=pdf, bereich=bmwi2012, sprache=de, rwb=true.pdf

Boccard, N. (2014). The cost of nuclear electricity: France after Fukushima. Energy Policy, 66, 450461.

Bullier, A., \& Milin, C. (2013). Alternative financing schemes for energy efficiency in buildings. ECEEE. 
Campoccia, A., Dusonchet, L., Telaretti, E., \& Zizzo, G. (2014). An analysis of feed-in tariffs for solar PV in six representative countries of the European Union. Solar Energy, 107, 530-542.

Chai, K. H., \& Yeo, C. (2012). Overcoming energy efficiency barriers through systems approach a conceptual framework. Energy Policy, 46, 460-472.

DDPP (Deep Decarbonization Pathways Project) (2015). Pathways to deep decarbonization 2015 report, SDSN - IDDRI.

DeCanio, S. J. (1998). The efficiency paradox: bureaucratic and organizational barriers to profitable energy-saving investments. Energy policy, 26(5), 441-454.

Dechezleprêtre, A., Glachant, M., Haščič, I., Johnstone, N., \& Ménière, Y. (2011). Invention and transfer of climate change-mitigation technologies: a global analysis. Review of Environmental Economics and Policy, 5(1), 109-130.

Dewar, J. A.; Builder, C.H.; Hix, W. M.; Levin, M. H. Assumption-Based Planning: A Planning Tool for Very Uncertain Times; Report MR-114-A; RAND: Santa Monica, 1993.

Dewey, J. (1927). The Public and its Problems. Holt and Company, New York.

Escobar Rangel, L., Lévêque, F. (2015) Revisiting the Cost Escalation Curse of Nuclear Power Generation: New Lessons from the French Experience, Economics of Energy and Environmental Policy, Vol. 4, September.

Fischedick, M. (2014). Transformation phases and corresponding challenges for a $100 \%$ renewable energy system. EUREC College of Members. Wuppertal Institute for Climate, Environment and Energy.

http://www.eurec.be/en/upload/docs/pdf/CoM_47/No1_Folien\%20MF\%20EUREC\%20Impuls_svi_1_ S.pdf

Global CCS Institute (2013). The Global Status of CCS. Global Carbon Capture and Storage Institute Ltd., Canberra (Update January 2013).

Grand, D., Le Brun, C., Vidil, R. Transition énergétique et mix électrique : les énergies renouvelables peuvent--- elles compenser une réduction du nucléaire? Revue de l’Energie, 619, Mai-Juin 2014.

Grübler, A. (2010). The costs of the French nuclear scale-up: A case of negative learning by doing. Energy Policy, 38(9), 5174-5188.

Haasnoot, M., Kwakkel, J. H., Walker, W. E., \& ter Maat, J. (2013). Dynamic adaptive policy pathways: A method for crafting robust decisions for a deeply uncertain world. Global Environmental Change, $23(2), 485-498$.

Haasnoot, M.; Middelkoop, H.; van Beek, E.; van Deursen, W.P.A. (2011) A method to develop sustainable water management strategies for an uncertain future. Sust. Develop., 19, 369-381.

Haasnoot, M.; Middelkoop, H.; Offermans, A.; van Beek, E.; van Deursen, W.P.A. (2012) Exploring pathways for sustainable water management in river deltas in a changing environment. Climatic Change, 115, 795-819. 
Hillebrandt, K., Samadi S., Fischedick M. (2015). Pathways to deep decarbonization in Germany, SDSN - IDDRI.

Hirth, L., Ueckerdt, F., \& Edenhofer, O. (2015). Integration costs revisited-An economic framework for wind and solar variability. Renewable Energy, 74, 925-939.

Jaffe, A. B., Stavins, R. N. (1994). Markets for energy efficiency: The energy-efficiency gap: What does it mean?, Energy Policy, Volume 22, Issue 10, Pages 804-810.

Johnstone, N., Haščič, I., \& Popp, D. (2010). Renewable energy policies and technological innovation: evidence based on patent counts. Environmental and Resource Economics, 45(1), 133-155.

Kann, A., \& Weyant, J. P. (2000). Approaches for performing uncertainty analysis in large-scale energy/economic policy models. Environmental Modeling \& Assessment, 5(1), $29-46$.

Kern, F., Gaede, J., Meadowcroft, J., \& Watson, J. (2016). The political economy of carbon capture and storage: An analysis of two demonstration projects. Technological Forecasting and Social Change, 102, 250-260.

Kumbaroğlu, G., Madlener, R., \& Demirel, M. (2008). A real options evaluation model for the diffusion prospects of new renewable power generation technologies. Energy Economics, 30(4), 1882-1908.

Kwakkel, J. H., Haasnoot, M., \& Walker, W. E. (2014). Developing dynamic adaptive policy pathways: a computer-assisted approach for developing adaptive strategies for a deeply uncertain world. Climatic Change, 1-14.

Lempert, R. J., \& Schlesinger, M. E. (2000). Robust strategies for abating climate change. Climatic Change, 45(3), 387-401.

Lévêque, F. (2014). The Economics and Uncertainties of Nuclear Power. Cambridge University Press.

Löschel, A., Erdmann, G., Staiß, F., Ziesing, H.J. (2012). Expertenkommission zum Monitoring-Prozess „Energie der Zukunft“. Stellungnahme zum ersten Monitoring-Bericht der Bundesregierung für das Berichtsjahr 2011. Berlin, Mannheim and Stuttgart.

http://www.bmwi.de/BMWi/Redaktion/PDF/M-O/monotoringbericht-stellungnahme-

lang,property=pdf, bereich $=$ bmwi2012, sprache $=$ de, $r w b=$ true.pdf

Löschel, A., Erdmann, G., Staiß, F., Ziesing, H.J. (2014a). Expertenkommission zum Monitoring-Prozess „Energie der Zukunft". Stellungnahme zum zweiten Monitoring-Bericht der Bundesregierung für das Berichtsjahr 2012. Berlin, Mannheim and Stuttgart.

http://www.bmwi.de/BMWi/Redaktion/PDF/M-O/monitoringbericht-energie-der-zukunftstellungnahme, property=pdf, bereich=bmwi2012, sprache=de, $r w b=$ true.pdf

Löschel, A., Erdmann, G., Staiß, F., \& Ziesing, H. J. (2014b). Expertenkommission zum MonitoringProzess "Energie der Zukunft". Stellungnahme zum ersten Fortschrittsbericht der Bundesregierung für das Berichtsjahr 2013. Berlin, Münster and Stuttgart.

http://www.bmwi.de/BMWi/Redaktion/PDF/M-O/monitoringberichtenergie-der-zukunftstellungnahme-2013, property=pdf, bereich $=$ bmwi2012, sprache $=$ de, $r w b=$ true. $p d f$ 
Löschel, A., Erdmann, G., Staiß, F., Ziesing, H.J. (2015). Stellungnahme zum vierten MonitoringBericht der Bundesregierung für das Berichtsjahr 2014. Berlin, Münster and Stuttgart. http://www.bmwi.de/BMWi/Redaktion/PDF/M-O/monitoringbericht-energie-der-zukunftstellungnahme-2014, property=pdf, bereich=bmwi2012,sprache=de,rwb=true.pdf

Marcantonini, C. \& Ellerman, A. D. (2015), The implicit carbon price of renewable energy incentives in Germany, accepted for publication in Energy Journal. Previous version published in EUI working paper, $2014 / 28$.

Markandya, A., \& Pemberton, M. (2010). Energy security, energy modelling and uncertainty. Energy Policy, 38(4), 1609-1613.

Mathy S., Criqui P., Hourcade JC. (2015) Pathways to Deep Decarbonization in 2050 in France. The French report of the Deep Decarbonization Pathways Project of the Sustainable Development Solutions Network and the Institute for Sustainable Development and International Relations.

Parson, E. A., \& Karwat, D. (2011). Sequential climate change policy. Wiley Interdisciplinary Reviews: Climate Change, 2(5), 744-756.

Quinet, A. (2009), La valeur tutélaire du carbone Rapport de la commission présidée par Alain Quinet. La documentation française, Rapport $\mathrm{n}^{\circ} 16,424 \mathrm{pp}$.

Ritzenhofen, I., \& Spinler, S. (2014). Optimal design of feed-in-tariffs to stimulate renewable energy investments under regulatory uncertainty a real options analysis. Energy Economics.

Schleich, J., \& Gruber, E. (2008). Beyond case studies: Barriers to energy efficiency in commerce and the services sector. Energy Economics, 30(2), 449-464.

Swanson, D.A. \& Bhadwal, S. (eds) (2009) Creating Adaptive Policies: A Guide for Policy-making in an Uncertain World. Sage.

Wagner, A., 2014. Residual demand modeling and application to electricity pricing. Energy J.35(2),45-73.

Walker, W. E., Marchau, V. A. W. J. \& Swanson, D. A. (2010) Addressing deep uncertainty using adaptive policies: Introduction to section 2. Technol Forecast Soc Chang 77(6):917-923.

Walker, W. E., Rahman, S. A., \& Cave, J. (2001). Adaptive policies, policy analysis, and policy-making. European journal of operational Research, 128(2), 282-289.

Yang, M., Blyth, W., Bradley, R., Bunn, D., Clarke, C., \& Wilson, T. (2008). Evaluating the power investment options with uncertainty in climate policy. Energy Economics, 30(4), 1933-1950.

Zeng, Y., Cai, Y., Huang, G., \& Dai, J. (2011). A review on optimization modeling of energy systems planning and GHG emission mitigation under uncertainty. Energies, 4(10), 1624-1656. 


\section{Supplementary material}

Table 1 : Targets in the French law on Energy Transition for Green Growth

\begin{tabular}{|c|c|c|c|c|c|c|}
\hline & Ref year & 2020 & 2025 & 2030 & 2040 & 2050 \\
\hline GHG emissions & 1990 & & & $-40 \%$ & & $-75 \%$ \\
\hline Final energy consumption & 2012 & & & $-20 \%$ & & $-50 \%$ \\
\hline Fossil energy consumption & 2012 & & & $-30 \%$ & & \\
\hline Renewables in overall consumption (\%) & & $23 \%$ & & $32 \%$ & & \\
\hline Renewables for heating (\%) & & & & $38 \%$ & & \\
\hline Renewables for fuel (\%) & & & & $15 \%$ & & \\
\hline Renewables for gas (\%) & & & & $10 \%$ & & \\
\hline Renewables for electricity (\%) & & & & $40 \%$ & & \\
\hline Nuclear power in electricity generation (\%) & & & $50 \%$ & & & \\
\hline Charging stations for electric vehicles & & & & 7 million & & \\
\hline Thermal rehabilitation projects per year & & 500,000 & 500,000 & 500,000 & 500,000 & 500,000 \\
\hline
\end{tabular}

\section{Source}

MEDDE (Ministère de l'Environnement, du Développement Durable et de l'Energie) 2015. Loi relative à la Transition Energétique pour la Croissance verte.

http://www.developpement-durable.gouv.fr/-Projet-de-loi-.html 
Table 2 : Current political climate and energy policy targets in Germany

\begin{tabular}{|c|c|c|c|c|c|}
\hline & \multirow{2}{*}{$\begin{array}{l}\text { Status quo } \\
2014\end{array}$} & \multicolumn{4}{|c|}{ Target } \\
\hline & & 2020 & 2030 & 2040 & 2050 \\
\hline GHG gas emissions (/1990) & $-28 \%$ & $-40 \%$ & $-55 \%$ & $-70 \%$ & $-80--95 \%$ \\
\hline \multicolumn{6}{|l|}{ Energy efficiency } \\
\hline Primary energy consumption (/2008) & $-9 \%$ & $-20 \%$ & \multicolumn{2}{|r|}{-} & $-50 \%$ \\
\hline Annual increase in final energy productivity & $0.6 \%(2008-13)$ & \multicolumn{4}{|c|}{$2.1 \%(2008-2050)$} \\
\hline Gross electricity consumption (/2008) & $-4 \%$ & $-10 \%$ & \multicolumn{2}{|r|}{-} & $-25 \%$ \\
\hline $\begin{array}{l}\text { Combined Heat and Power share in thermal } \\
\text { electricity generation }\end{array}$ & $22 \%$ & $25 \%$ & \multicolumn{3}{|c|}{-} \\
\hline \multicolumn{6}{|l|}{ Renewable energy } \\
\hline Share in gross electricity consumption & $27 \%$ & \multicolumn{2}{|c|}{$40-45 \%(2025)$} & $55-60 \%(2035)$ & $>80 \%$ \\
\hline Share in final energy consumption for heating & $10 \%$ & $14 \%$ & \multicolumn{3}{|c|}{-} \\
\hline Share in fuel consumption & $5 \%$ & $10 \%$ & & - & \\
\hline Share in gross final energy consumption & $14 \%$ & $18 \%$ & $30 \%$ & $45 \%$ & $60 \%$ \\
\hline \multicolumn{6}{|l|}{ Buildings } \\
\hline Heat demand (no reference defined) & n.a. & $-20 \%$ & & - & \\
\hline Primary energy demand (no reference defined) & n.a. & \multicolumn{3}{|c|}{-} & $-80 \%$ \\
\hline $\begin{array}{l}\text { Annual rate of energy-related building } \\
\text { refurbishment }\end{array}$ & $1 \%(2005-2008)$ & \multicolumn{4}{|l|}{$2 \%$} \\
\hline \multicolumn{6}{|l|}{ Transport } \\
\hline Final energy consumption (/2005) & $-5 \%$ & $-10 \%$ & \multicolumn{2}{|r|}{-} & $-40 \%$ \\
\hline Number of electric vehicles & 24,000 & $1 \mathrm{~m}$ & $6 \mathrm{~m}$ & & \\
\hline
\end{tabular}

Sources: BMWi and BMU, 2010; EEG, 2014; EEWärmeG, 2008; BMWi, 2015a, b; EU, 2009; UBA, 2015; AGEB,

2015a, b, c; Diefenbach et al., 2010; NPE, 2014 


\section{Sources}

AGEB, Arbeitsgemeinschaft Energiebilanzen (2015a). Energieverbrauch in Deutschland im Jahr 2014. http://www.ag-energiebilanzen.de/index.php?article_id=29\&fileName=ageb_jahresbericht2014.pdf

AGEB, Arbeitsgemeinschaft Energiebilanzen (2015b). Energieverbrauch dank milder Witterung deutlich gesunken.

http://www.ag-

energiebilanzen.de/index.php?article_id=29\&fileName=ageb_pressedienst_01_2015_jahresbericht.p df

AGEB, Arbeitsgemeinschaft Energiebilanzen (2015c). Bruttostromerzeugung in Deutschland ab 1990 nach Energieträgern.

http://www.ag-

energiebilanzen.de/index.php?article_id=29\&fileName=20150227_brd_stromerzeugung1990-

2014.pdf

BMWi, Federal Ministry for Economic Affairs and Energy (2015a). Zeitreihen zur Entwicklung der erneuerbaren Energien in Deutschland unter Verwendung von Daten der Arbeitsgruppe Erneuerbare Energien-Statistik (AGEE-Stat).

http://www.erneuerbare-energien.de/EE/Redaktion/DE/Downloads/zeitreihen-zur-entwicklung-dererneuerbaren-energien-in-deutschland-1990-2014.pdf?_blob=publicationFile\&v=3

BMWi, Federal Ministry for Economic Affairs and Energy (2015b). Zahlen und Fakten. Energiedaten. Nationale und Internationale Entwicklung.

http://bmwi.de/BMWi/Redaktion/Binaer/energie-daten-

gesamt, property=blob, bereich=bmwi2012, sprache $=$ de, $r w b=$ true. $x l s$

BMWi, Federal Ministry of Economics and Technology, BMU, Federal Ministry for the Environment, Nature Conservation and Nuclear Safety (2010). Energy Concept for an Envrionmentally Sound, Reliable and Affordable Energy Supply (Energiekonzept für eine umweltschonende, zuverlässige und bezahlbare Energieversorgung).

http://www.germany.info/contentblob/3043402/Daten/3903429/BMUBMWi_Energy_Concept_DD.p $\mathrm{df}$

Diefenbach, N.; Cischinsky, H.; Rodenfels, M. and Clausnitzer, K.-D. (2010). Datenbasis Gebäudebestand Datenerhebung zur energetischen Qualität und zu den Modernisierungstrends im deutschen Wohngebäudebestand. IWU, Institute for Housing and the Environment and BEI, Bremen Energy Institute.

http://datenbasis.iwu.de/dl/Endbericht_Datenbasis.pdf

EEG, Renewable Energy Sources Act (2014). Gesetz für den Ausbau erneuerbarer Energien. http://www.bmwi.de/BMWi/Redaktion/PDF/G/gesetz-fuer-den-ausbau-erneuerbarer-

energien, property=pdf, bereich=bmwi2012, sprache=de,rwb=true.pdf

EEWärmeG, Renewable Energies Heat Act (2008). Gesetz zur Förderung Erneuerbarer Energien im Wärmebereich.

http://www.gesetze-im-internet.de/bundesrecht/eew_rmeg/gesamt.pdf 
EU, European Union (2009). Directive 2009/28/EC of the European Parliament and of the Council of 23 April 2009 on the promotion of the use of energy from renewable sources and amending and subsequently repealing Directives 2001/77/EC and 2003/30/EC.

http://eur-lex.europa.eu/legal-content/EN/TXT/PDF/?uri=CELEX:32009L0028\&from=EN

NPE, Nationale Plattform Elektromobilität (2014). Fortschrittsbericht 2014 - Bilanz der Marktvorbereitung.

http://www.bmbf.de/pubRD/NPE_Fortschrittsbericht_2014_barrierefrei.pdf

UBA, Federal Environment Agency (2015). UBA-Emissionsdaten 2014 zeigen Trendwende beim Klimaschutz.

http://www.umweltbundesamt.de/sites/default/files/medien/381/dokumente/pi_2015_31_03_ubaemissionsdaten_2014_zeigen_trendwende_beim_klimaschutz.pdf 